\title{
The influence of fertilizer type and time of application on growth and forage productivity of mung bean
}

\author{
ARD ALSHAM ADAM MOHAMMEDALTOM, YASSIN MOHAMED IBRAHIM DAGASH ${ }^{\boldsymbol{\nu}}$ \\ College of Graduate Studies, Sudan University of Science and Technology, Shambat, Khartoum, Sudan. "email: dagash501@gmail.com
}

Manuscript received: 30 September 2016. Revision accepted: 18 June 2017.

\begin{abstract}
Mohammedaltom AAA, Dagash YMI. 2017. The effect of fertilizer type and time of application on growth and forage productivity of mung bean. Asian J Agric 1: 22-28. A field experiment was conducted on April 3, 2016, at the Demonstration Farm of College of Agricultural Studies, Sudan University of Sciences and Technology, Shambat, Khartoum, Sudan to study the effect of some fertilizers and their time of application on growth and forage productivity of mung bean. The treatments were arranged factorially in split-plot trial with four replications. Application time was assigned to the main plot as three times of application: before sowing, with sowing and after sowing. Types of fertilizers as the subplots, included four types of fertilizers: without fertilizer (control), $50 \mathrm{~kg}^{-1}$ (organic manure), $100 \mathrm{~kg} \mathrm{ha}^{-1}$ (diammonium phosphate), and $10 \mathrm{~L}$ ha-1 (humic acid). Different characteristics measured included: plant height $(\mathrm{cm})$, stem thickness $(\mathrm{cm})$, number of branches per plant, number of leaves per plant, fresh weight/plant $(\mathrm{g})$ as well as dry weight/plant $(\mathrm{g})$. The results revealed that there was a highly significant difference for types and application time of fertilizers and their interaction on plant height, number of leaves, and fresh forage and dry forage. Highly significant differences $(p \leq 0.01)$ were recorded in types of fertilizers and interaction between different application times and types of fertilizers for number of branches and significant difference $(p \leq 0.05)$ of application time for number of branches and stem diameter. There was no significant difference in types of fertilizers for stem diameter. The highest height of the plant $(28.78 \mathrm{~cm})$, the highest number of branches/plant $(9.37)$, the maximum stem diameter $(6.43 \mathrm{~cm})$, the largest number of leaves/plant $(31.69)$, the best fresh weight $\left(815 \mathrm{~kg} \mathrm{ha}^{-1}\right)$ and dry weight $\left(161 \mathrm{~kg}\right.$ ha $\left.{ }^{-1}\right)$ were recorded for the treatment of $50 \mathrm{~kg} \mathrm{ha}^{-1}$ organic manure applied after sowing.
\end{abstract}

Keywords: Fertilizer, plant growth, forage, mung bean

\section{INTRODUCTION}

Fodders are a very vital resource for the development of the agricultural economy within poor countries for livestock raising (Zahid et al. 2013). Fodder crops are crops that are cultivated primarily for animal feed. All fodder crops whether grasses, legumes and root crops are fed to animals, either as green, hay or silage products (Wanas et al. 2007). The traditional system for forage production in Sudan favors high yields at the expense of nutritive value. This is because fodders were mainly produced as cash crops. Such system requires fast growing, highly productive cultivars to minimize costs of production. These requirements are largely met by fodder sorghum, Abu Sab'in (Maarouf and Zeinab 2013). The total area of forage production in Sudan is estimated to be about 126,000 ha, or almost half in Khartoum state (Zaroug et al. 1997). The recent statistics of the Sudan Ministry of Agriculture (2015) showed that the area of forage crops represented about $80 \%$ of the area cultivated in Khartoum state. This area was almost doubled from 114513 in (2006) to 239535 feddans in (2015). 81\% of the area under forage production was occupied by fodder sorghum, Abu Sab'in and alfalfa (Sudan Ministry of Agriculture 2015). The system of forage crop production adopted in Sudan, the green chopping system, does not allow a continuous supply of animal feed. Referring to the recent statistics, about $90 \%$ of the animal wealth in Sudan relies on natural pastures and crop residues (NCS 1999). This expansion was due to growing importance of forage crops, due to the increased attention to dairy production, particularly around urban centers and to satisfy the needs of increasing animals for meat. The demand is continuously increasing due to population growth and mass immigration of rural communities. In addition to this, a remarkable activity of cattle and sheep export has resulted in increasing the area of fodder crops grown primarily under irrigation (Idris et al. 2013).

Legume fodder is important for livestock production because it is rich in protein, minerals, phosphorus, calcium, and vitamins (Bogdan 1977, Unkovich et al. 1997). Dairy animals require a green legume crop to cover up the balance of their protein requirement. Mung bean (Vigna radiata $\mathrm{L}$.) Wilczek syn. also called green gram and golden bean is an important summer annual pulse crop, belongs to genus Vigna and family Leguminosae. India is considered its native country, and it is cultivated in Pakistan, USA, Europe (Zaid et al. 2012), Bangladesh, Cambodia, Indonesia, the Philippines, Thailand, Vietnam (Somashekaraiah et al. 1992), Uganda (Apioibedo 2014), Australia, China (Imrie and Lawn 1991) and Egypt (Ashour et al. 1994) and Iran (Paroda et al. 1987). From Asia, it spread into the Middle East, the Pacific Islands, East Africa, Australia, and the Americas, but Asia continues to be the region of major production (Nassar 2013). India is the largest producer of mung bean in the 
world (54\%), the average productivity is $550 \mathrm{~kg} \mathrm{ha}^{-1}$ (ICAR. 2008) and produced higher forage 2.2-ton ha- $\mathrm{ha}^{-1}$ (Twidwel et al. 1992). In South Asia, improved varieties of mung bean are planted on an area of 3 million hectares, and with a total annual production of 3.1 million tons both under rain-fed and irrigated conditions (Shanmugasundaram et al. 2009). In Pakistan, it was planted on an area of 2.5 million hectares with a total annual production of 1.8 million tons, and with an average yield of $723 \mathrm{~kg}$ ha-1. Out of the total area in Pakistan, Khyber Pakhtunkhwa covered an area of 10.1 thousand hectares with the production of 6.4 thousand tons producing an average yield of $634 \mathrm{~kg} \mathrm{ha}^{-1}$ (Minfal 2008) and, the average yield in Pakistan during the year 20092010 was $709 \mathrm{~kg}$ per hectare (Ali et al. 2000).

In Sudan, mung bean is a new crop, and it may be a commercially promising pulse crop and can be grown as a forage crop. Local production of pulses is not sufficient to meet the increasing demand for human utilization. Therefore, to meet the situation, it is necessary to boost up the production. Inadequate supply of feed-in quantity and quality is responsible for the low productivity of animals.

Animals depend entirely on natural pastures for their feed. This source is only adequate for their survival during the wet season but inadequate during the dry season. This has resulted in the characterized limitation posed by nonavailability of all-year-round feed resources due to prolonged dry season (Oladotun et al. 2003, Odeyinka and Okunade 2005). There is a need to improve pasture production through properly planned management and a need for better forage cultivars that maintain a continuous supply of forages. Such management practices include cutting management and introducing high-yielding new crops with short-growing seasons. With proper management practices, it can be considered an effective tool for narrowing the food gap in Sudan as well as cultivation of mung bean and the use of fertilizers. Genetic potential of legumes is not obtained at field due to poor soil nutrient status, mineral deficiency (Maskey et al. 2004) and nodulation are poor on Shambat soil. They are worldwide agricultural problems causing yield and quality loss (Liu 2001). In this context, a low-cost technique is needed to incorporate nutrient (micronutrient and macronutrient) into the plant system, thus it enhances growth, and boost up crop yield and nutrient status in plants, thus nutrient deficiency can be remove and higher yield and vigor seedling can be achieved in mung bean, by using the best fertilizers and optimum application time.

The objectives of this study were: (i) to examine the influence of different types of fertilizers on growth and forage productivity of Mung bean, (ii) to determine optimum application time of fertilizer to enhance Mung bean forage productivity.

\section{MATERIALS AND METHODS}

\section{Site of experiment}

This experiment was conducted at the experimental farm in the College of Agricultural Studies-Sudan University of Science and Technology (Shambat), from April to June 2016. Shambat is located between latitudes $\left(15.40^{\circ}\right.$ North and $32.32^{\circ}$ East $)$ and altitudes of 380 meters above sea level. The climate is characterized by semidesert tropics with a low percentage of humidity, average rainfall of $158 \mathrm{~mm}$ per annum, temperature of 20.3-36.1 ${ }^{\circ} \mathrm{C}$ clay soil (Khairy 2010), and soil pH 7.5-8.7 (Hamdon 2001).

\section{Experimental design}

The treatments were arranged factorially in split-plot design with four replications. The main plot consisted of three application times, i.e., $\mathrm{T}_{1}=$ before sowing, $\mathrm{T}_{2}=$ with sowing and $\mathrm{T}_{3}=$ after sowing. The subplot consisted of four fertilizers i.e., $\mathrm{F}_{0}=$ control (no fertilizer), $\mathrm{F}_{1}$ =diammonium phosphate, $\mathrm{F}_{2}=$ organic manure, $\mathrm{F}_{3}=$ humic acid.

\section{Plant material}

Mung bean seeds used in the study were obtained from the College of Agricultural Studies, Sudan University of Science and Technology, Shambat.

\section{Cultural practices}

Preparation of soil samples. The soil mixture consisted of clay and sand percentage (2: 1) in plastic pots. Pot area was $1.4 \mathrm{~m} 2$ and each pot contained $10 \mathrm{~kg}$ soil sample. Sub samples were taken before sowing and analyzed in the Laboratory Soil and Water Science, College of Agricultural StudiesCAS), Sudan University of Science and Technology, Shambat, Khartoum, Sudan. EC, $\mathrm{pH}$, and soluble salts were determined on paste saturation extract (Ritchard 1954) by the use of $\mathrm{pH}$ meter (model 3510), EC meter (model M35). Na and $\mathrm{K}$ were estimated using direct flame photometry in soil extract (flame photometer (model 410)). CaCO3 was estimated using a calcimeter, Model (Eijkelkamp). Total nitrogen was performed using the Kjeldahl method (Ryan et al. 2001). For available phosphorous, O'lsen (1954) method was using a spectrophotometer model (6305). Organic carbon was determined by the Walkley and Black method (1934). The amount of exchangeable potassium was estimated using direct flame photometry in soil extract (Ryan et al. 1996). Soil texture was determined using Particle Size Determination (Pipette Method), and textural classes were defined USDA textural triangle, appendix (1). As activation dose, recommended $\mathrm{N}\left(40 \mathrm{~kg} \mathrm{ha}^{-1}\right)$ by using urea $6 \mathrm{~g}$ per pot was applied in each pot before sowing.

Sowing. $30 \mathrm{~g}$ of seeds were mixed thoroughly with $0.15 \mathrm{~g}$ Thiram, and immediately sown on the 3rd of April 2016 in pots at the rate of 3 seeds per hole.

Irrigation. The first irrigation was done immediately after sowing and then when necessary.

Treatment. Pots were fertilized as per treatments described below. Diammonium phosphate $100 \mathrm{~kg} \mathrm{ha}^{-1}(15$ 
g per pot), organic manure $50 \mathrm{~kg} \mathrm{ha}^{-1}(7.5 \mathrm{~g}$ per pot) and humic acid $10 \mathrm{~L} / \mathrm{ha}(1.5 \mathrm{ml}$ per pot). All fertilizers were incorporated into the soil before sowing (15 days), at sowing and after sowing of seeds (15 days).

The treatments were arranged as follows:

Application time: (i) 15 days before sowing (B.S), (ii) With sowing (W.S), (iii) 15 days after sowing (A.S)

Fertilizers: (i) Diammonium Phosphate (46\% P2O5, $18 \% \mathrm{~N}$ ) at $100 \mathrm{~kg} \mathrm{ha}^{-1}$ or $15 \mathrm{~g}$ per pot. (ii) Humic Acid $(12 \% \mathrm{~N}, 15 \%$ Humic Acid, $3 \% \mathrm{~K} 2 \mathrm{o})$ at $10 \mathrm{~L} / \mathrm{ha}$ or $1.5 \mathrm{~mL}$ per pot. (iii) Organic manure $(0.062 \%$ O.M, $0.107 \%$ O.C, $1.232 \% \mathrm{~N}, 61 \% \mathrm{P}, 4.6 \mathrm{~mL} / \mathrm{L} \mathrm{K}, 40.7 \mathrm{~mL} / \mathrm{L} \mathrm{Ca}, 119.3 \mathrm{~mL} / \mathrm{L}$ $\mathrm{Mg}, \quad 32.6 \mathrm{~mL} / \mathrm{L} \quad \mathrm{Na}, \quad 6.45 \mathrm{~mL} / \mathrm{L} \quad \mathrm{Fe}, \quad 1.797 \mathrm{~mL} / \mathrm{L} \quad \mathrm{Mn}$, $0.028 \mathrm{~mL} / \mathrm{L} \mathrm{Su}, 0.108 \mathrm{~mL} / \mathrm{L} \mathrm{Co}, 0.15 \mathrm{~mL} / \mathrm{L} \mathrm{Pb}, 0.114 \mathrm{~mL} / \mathrm{L}$ $\mathrm{Zn}, 36.1 \% \mathrm{~m}, 58.16 \%$ Ash, 1: $2 \mathrm{C}: \mathrm{N}, 6.5 \mathrm{pH}$, 23.5/D.S.ME.C, at $50 \mathrm{~kg} \mathrm{ha}^{-1}$ or $7.5 \mathrm{~g}$ per pot.

Harvesting. After 75 days from sowing the crop was ready for harvesting. Removal of the vegetable parts at soil surface was done manually using clipper for stover production.

\section{Data collection}

Plant height growth. After four weeks from sowing (30 days), four plants of mung bean were randomly selected from each pot to determine growth stages and the period between readings was 15 days.

Plant height (cm). Plant height was measured from the ground level to tip of the stem, from four plants of mung bean randomly selected from each pot, using a measuring tape then the mean plant height was recorded.

Stem diameter $(\mathbf{c m})$. Four plants of mung bean were randomly selected from each pot and stem diameter was measured for each plant separately at the middle internodes using meter and the average per plant was recorded

Number of branches per plant. Four plants of mung bean were randomly selected from each pot and number of branches was counted and then the mean per plant was recorded.

Number of leaves per plant. The number of leaves was counted from four plants of mung bean randomly selected from each pot and then the mean per plant was recorded.

Fresh yield per plant (g). At harvest (75 DAS) four plants were weighted and the mean fresh yield weight per plant was recorded.

Dry yield per plant $(\mathrm{g})$. The fresh yield of four plants were oven dried at $80 \mathrm{C}$ for 48 hours to constant weight and the mean dry yield weight per plant was recorded. The fresh yield and dry yield $\left(\mathrm{kg} \mathrm{ha}^{-1}\right)$ were calculated as follows:

Yield $=$ Area in hectare $\left(10000 \mathrm{~m}^{2}\right) \times$ forage weight per $\mathrm{m}^{2}(\mathrm{~g})$ Weight unit (1000)

\section{Statistical analysis}

Data were statistically analyzed according to split-plot design using MSTAT-C package. The mean values were separated by Least Significant Difference (L.S.D) (Gomez and Gomez 1984).

\section{RESULTS AND DISCUSSION}

\section{Plant height (cm)}

The analysis of variance showed that a higher significant effect of time of fertilizer application and types of fertilizers as well as their interaction on plant height (Table 1). The tallest plants were recorded at application time after sowing while shorter plants were recorded at application time at sowing (Table 2). The types of fertilizers promoted significantly different plant heights. The highest plants were observed in organic manure and the shortest plants were recorded in humic acid (Table 3). Plant height ranged from $15.41 \mathrm{~cm}$ to $28.78 \mathrm{~cm}$. Maximum plant height $(28.78 \mathrm{~cm})$ was found with $50 \mathrm{~kg}$ organic manure per ha application after sowing which was statistically higher than other treatments. Minimum plant height was observed for organic manure added before sowing $(15.41 \mathrm{~cm})$. It was clear that with the fertilizer added after sowing, the plant height was increased with the organic manure (Table 4). These results agreed with those of Malihe et al. (2014) who reported a significant effect of organic fertilizers on plant height and while Bhuiyan et al. (2008), Shukla and Dixit (1996) and Sharma and Singh (1997) reported that application of phosphorus enhanced the plant height significantly.

\section{Stem thickness (cm)}

The results showed that the time of fertilizer application and types of fertilizers had higher significant effect on stem thickness per plant, while their interaction had no significant effect on stem thickness per plant (Table 1). Stem thickness was thick at application time before and at sowing and the thin stem, thickness was observed at application time after sowing (Table2). Organic manure produced thick stem thickness per plant $(5.68 \mathrm{~cm})$, while thin stem thickness per plant $(5 \mathrm{~cm})$ was produced by humic acid (Table 3). Interaction between time of fertilizer application and types of fertilizers had also significant effect on stem thickness per plant pots treated with $50 \mathrm{~kg}$ $\mathrm{ha}^{-1}$ organic manure added after sowing produced thick stem thickness $(6.43 \mathrm{~cm})$, while thin stem thickness $(4.18$ $\mathrm{cm}$ ) was recorded in pots with $100 \mathrm{~kg} \mathrm{ha}^{-1}$ diammonium phosphate added at sowing (Table 4). These results were not in agreement with those of Iqbal et al. (2012) who showed that significant results were obtained in stem with an appropriate supply of phosphorus.

Stem increase with organic manure $50 \mathrm{~kg} \mathrm{ha}^{-1}$ added after sowing was recorded $(6.43 \mathrm{~cm})$ (table 4$)$. These results were not in accordance with those of Nemat et al. (2000) who reported that increasing levels of phosphorus lead to the increment in stems.

\section{Number of branches}

Number of branches per plant was significantly higher at the time of fertilizer application and types of fertilizers and significantly different with their interaction (Table 1). The lowest number of branches per plant was noticed in application at sowing while higher number of branches per plant was recorded in application after sowing (Table 2). 
Number of branches was increased with types of fertilizers. The highest number of branches (8.10) was observed with the organic manure application at $50 \mathrm{~kg} \mathrm{ha}^{-1}$ which was statistically higher than other treatments. The lowest values (7.37 and 7.35) were recorded with the diammonium phosphate and control respectively (Table 3). These results were confirmed earlier by Ali (1993) who showed that the number of branches per plant was not affected by level of phosphorus. In contrast, Muhammad et al. (2014) found that the number of branches per plant was significantly influenced by phosphorus application.

With $50 \mathrm{~kg}$ organic manure per ha added after sowing produced maximum number of branches per plant (9.37), while minimum number of branches per plant (5.12) was recorded with $100 \mathrm{~kg} \mathrm{ha}^{-1}$ diammonium phosphate added at sowing (Table 4). Malihe et al. (2014) stated that the number of branches was not affected when using organic fertilizers which did not agree with results of this study.

\section{Number of leaves}

Time of fertilizer application and types of fertilizers, as well as their interaction, had higher significant effects on number of leaves per plant (Table 1). Number of leaves per plant was influenced significantly by the time of fertilizer application. The highest values of the number of leaves were found after sowing application. While the lowest values of the number of leaves were observed both before sowing and at sowing application (Table 2). The number of leaves was significantly affected by types of fertilizers. The highest number of leaves was recorded with the organic manure application. Number of leaves in pots treatment with humic acid fertilizer was lowest (Table 3). This contradicted with Eldm, (2004) who reported that number of leaves per and yield was gradually and significantly increased with the application of humic substances. The interaction between time of fertilizer application and types of fertilizers had higher significant effect on number of leaves per plant, the pots treated with $50 \mathrm{~kg}$ organic manure per ha added after sowing produced maximum number of leaves per plant (31.69), while minimum number of leaves per plant (17.88) was recorded in at sowing application by $100 \mathrm{~kg} \mathrm{ha}^{-1}$ diammonium phosphate (Table 4). These results were supported earlier by El-Banna et al. (2006) who found that the increase in leaves number due to the application of organic components had stimulatory effects on cell division and enlargement, protein and nucleic acid synthesis. But this is not in line with Bhuiyan et al. (2008) who found that plants produced a significantly higher number of leaves with phosphorus and highest number of leaves (22.84) was found with phosphorus added at the rate of $40 \mathrm{~kg} \mathrm{ha}{ }^{1}$, which was statistically significant.

\section{Fresh forage yield $\left(\mathrm{kg} \mathrm{ha}^{-1}\right)$}

The fresh forage yield was affected by time of fertilizer application and types of fertilizers as well as their interaction (Table1). Time of fertilizer application had high significantly affected the fresh forage yield. The highest fresh forage yield $\left(\mathrm{kg} \mathrm{ha}^{-1}\right)$ was recorded from the pots application time after sowing. While the least fresh forage yield $\left(\mathrm{kg} \mathrm{ha}^{-1}\right)$ was counted in pots application time at sowing (Table2). $50 \mathrm{~kg} \mathrm{ha}^{-1}$ organic manure performed better than other fertilizers doses. The lowest fresh forage yield was recorded in humic acid fertilizer. Diammonium phosphate increased fresh forage yield significantly over control (Table 3). These results confirm the findings of Bhuiyan et al. (2008) and Manpreet et al. (2004) who reported that the effect of phosphorus on Stover yield of mung bean was influenced significantly at harvest. The highest fresh forage yield $\left(815.8 \mathrm{~kg} \mathrm{ha}^{-1}\right)$ was recorded in $50 \mathrm{~kg} \mathrm{ha}^{-1}$ organic manure after sowing application, which was significantly higher than other treatments. After sowing application humic acid fertilizer and control were statistically similar. The lowest fresh forage yield was 146 $\mathrm{kg} \mathrm{ha}^{-1}$ recorded with $100 \mathrm{~kg} \mathrm{ha}^{-1}$ added at sowing. Their results agreed with those of Bhuiyan et al. (2008) who reported with increasing Phosphorus rate, Stover yield decreased significantly.

\section{Dry forage yields $\left(\mathrm{kg} \mathrm{ha}^{-1}\right)$}

Dry forage yields of mung beans were influenced significantly by the time of fertilizer application, types of fertilizers and their interaction (Table 1). The highest forage yield $106.1 \mathrm{~kg} \mathrm{ha}^{-1}$ was found with application after sowing, which was significantly higher than other treatments. The lowest forage yield was $85.3 \mathrm{~kg} \mathrm{ha}^{-1}$ recorded with application at sowing (Table 2). Moreover, the single effect of types of fertilizers on mung bean forage yields was also significantly influenced. The forage yield with organic manure was significantly higher than the forage yield recorded with humic acid fertilizer (Table 3). Sarwar et al. (2014) showed that the maximum straw yield on mung beans was recorded in the treatment where humic acid was applied at $50 \mathrm{~kg} \mathrm{ha}^{-1}$. Dry forage yield of mung bean was significantly influenced by interaction of time of fertilizer application, types of fertilizers. The maximum forage yield $161 \mathrm{~kg} \mathrm{ha}^{-1}$ was obtained from pots fertilized by $50 \mathrm{~kg}$ organic manure per ha after sowing application. The minimum forage yield $40 \mathrm{~kg} \mathrm{ha}^{-1}$ was obtained from diammonium phosphate application at sowing (Table 4). This result is not in agreement with that of Bhuiyan et al. (2008) who showed the significant effect of phosphorus, on dry weight of mung bean. Singh and Agrawal, (2007) stated that higher availability of nutrients in organic fertilizer was the main factor contributing to higher biomass of plants, which in line with the results of this study.

\section{Plant height growth}

A significant effect of time of fertilizer application and types of fertilizers and their interaction in early growth stage such as up to 30 days after sowing (days) was revealed (Figure 1), but at later stage, there were higher significant difference among the of time of fertilizer application and types of fertilizers and their interaction. 
Table 1. F-value of plant height $(\mathrm{cm})$, number of branches per plant, number of leaves per plant, fresh weight $\left(\mathrm{kg} \mathrm{ha}^{-1}\right)$ and dry weight $\left(\mathrm{kg} \mathrm{ha}^{-1}\right)$ of mung bean under time of fertilizer application and types of fertilizers.

\begin{tabular}{|c|c|c|c|c|c|c|c|}
\hline \multirow{2}{*}{$\begin{array}{l}\text { Source of } \\
\text { Variation }\end{array}$} & \multirow[b]{2}{*}{$\begin{array}{l}\text { Degree of } \\
\text { freedom }\end{array}$} & \multicolumn{6}{|c|}{ F-values } \\
\hline & & $\begin{array}{c}\text { Plant height } \\
(\mathrm{cm})\end{array}$ & $\begin{array}{l}\text { Stem thickness } \\
\text { (cm) }\end{array}$ & $\begin{array}{c}\text { Number of } \\
\text { branches per plant }\end{array}$ & $\begin{array}{c}\text { Number of leaves } \\
\text { per plant }\end{array}$ & $\begin{array}{c}\text { Fresh weight } \\
\left(\mathrm{kg.ha}^{-1}\right)\end{array}$ & $\begin{array}{c}\text { Dry weight } \\
\left(\text { kg.ha }^{-1}\right)\end{array}$ \\
\hline Replication & 3 & 1.62 & 4.27 & 0.31 & 3.35 & 15.52 & 7.36 \\
\hline Application Time (A) & 2 & $34.03 * *$ & $4.69 *$ & $9.16^{*}$ & $26.58 *$ & $2223.13 * *$ & $68.22 * *$ \\
\hline Error 1 & 6 & - & - & - & - & - & - \\
\hline Fertilizers (F) & 3 & $40.39 * *$ & $1.36^{\mathrm{NS}}$ & $14.17 * *$ & $17.38 * *$ & $383.98 * *$ & $34.31 * *$ \\
\hline$(\mathrm{A} \times \mathrm{F})$ & 6 & $130.99 * *$ & $3.38 *$ & $33.29 * *$ & $37.64 * *$ & $954.38 * *$ & $81.70 * *$ \\
\hline Error & 27 & - & - & - & - & - & - \\
\hline Total & 47 & - & - & - & - & - & - \\
\hline $\begin{array}{l}\text { Error Mean Square } \\
\text { (EMS) }\end{array}$ & - & 0.78 & 0.74 & 0.24 & 2.22 & 173.90 & 77.66 \\
\hline Coefficient of & & & & & & & \\
\hline Variance (C.V. \%) & - & 4.10 & 15.90 & 6.68 & 6.03 & 3.14 & 9.80 \\
\hline L.S.D at $5 \%$ & - & 0.369 & 0.360 & 0.20 & 0.62 & 5.52 & 3.69 \\
\hline $\mathrm{Se} \pm(\mathrm{A})$ & - & 0.19 & 0.14 & 0.15 & 0.25 & 1.96 & 1.74 \\
\hline $\mathrm{Se} \pm(\mathrm{F})$ & - & 0.25 & 0.24 & 0.14 & 0.43 & 3.80 & 2.54 \\
\hline $\mathrm{Se} \pm(\mathrm{A} \times \mathrm{F})$ & - & 0.44 & 0.43 & 0.24 & 0.74 & 6.59 & 4.40 \\
\hline
\end{tabular}

Note: $\mathrm{NS}=$ not significant, $*=$ statistically significant difference at $\mathrm{p}=0.05, * *=$ statistically significant difference at $\mathrm{p}=0.01$

Table 2. Mean comparison of parameters studied of mung bean under time of fertilizer application

\begin{tabular}{lcccccc}
\hline \multicolumn{1}{c}{ Treatments } & $\begin{array}{c}\text { Plant height Stem diameter } \\
(\mathbf{c m})\end{array}$ & $\begin{array}{c}\text { Number of branches } \\
\text { per plant }\end{array}$ & $\begin{array}{c}\text { Number of leaves } \\
\text { per plant }\end{array}$ & $\begin{array}{c}\text { Fresh weight } \\
\left(\mathbf{k g . h a}^{-1}\right)\end{array}$ & $\begin{array}{c}\text { Dry weight } \\
\left(\mathbf{k g}^{-1} \mathbf{m a}^{-1}\right)\end{array}$ \\
\hline Before sowing application & $20.31 \mathrm{C}$ & $5.55 \mathrm{~A}$ & $7.28 \mathrm{~B}$ & $24.03 \mathrm{~B}$ & $398 \mathrm{~B}$ & $85.31 \mathrm{~B}$ \\
With sowing application & $21.71 \mathrm{~B}$ & $5.04 \mathrm{~B}$ & $7.01 \mathrm{C}$ & $23.89 \mathrm{~B}$ & $339.8 \mathrm{C}$ & $78.38 \mathrm{C}$ \\
After sowing application & $22.62 \mathrm{~A}$ & $5.62 \mathrm{~A}$ & $7.92 \mathrm{~A}$ & $26.20 \mathrm{~A}$ & $521.3 \mathrm{~A}$ & $106.1 \mathrm{~A}$ \\
\hline
\end{tabular}

Note: The same letter in each column shows non-significant differences using LSD 5\%.

Table 3. Mean comparison of parameters studied of mung bean under types of fertilizers

\begin{tabular}{|c|c|c|c|c|c|c|}
\hline Treatments & $\begin{array}{c}\text { Plant height } \\
(\mathbf{c m})\end{array}$ & $\begin{array}{c}\text { Stem thickness } \\
(\mathrm{cm})\end{array}$ & $\begin{array}{c}\text { Number of branches } \\
\text { per plant }\end{array}$ & $\begin{array}{c}\text { Number of leaves } \\
\text { per plant }\end{array}$ & $\begin{array}{c}\text { Fresh weight } \\
\left(\mathrm{kg} \mathrm{ha}^{-1}\right)\end{array}$ & $\begin{array}{c}\text { Dry weight } \\
\left(\mathrm{kg} \mathrm{ha}^{-1}\right)\end{array}$ \\
\hline$\overline{\text { Control }}$ & $21.48 \mathrm{C}$ & $5.45 \mathrm{~A}$ & $7.35 \mathrm{~B}$ & $24.94 \mathrm{~B}$ & $388.8 \mathrm{C}$ & $84.33 \mathrm{C}$ \\
\hline Organic Manure & $23.05 \mathrm{~A}$ & $5.68 \mathrm{~A}$ & $8.10 \mathrm{~A}$ & $27.06 \mathrm{~A}$ & $523.8 \mathrm{~A}$ & $109.7 \mathrm{~A}$ \\
\hline Diammonium phosphate & $22.35 \mathrm{~B}$ & $5.50 \mathrm{~A}$ & $7.37 \mathrm{~B}$ & $24.02 \mathrm{C}$ & $416.4 \mathrm{~B}$ & $91.42 \mathrm{~B}$ \\
\hline Humic acid & 19.32D & $5 \mathrm{~B}$ & $6.79 \mathrm{C}$ & $22.81 \mathrm{D}$ & $349.7 \mathrm{D}$ & $74.33 \mathrm{D}$ \\
\hline
\end{tabular}

Note: The same letter in each column shows non-significant differences using LSD 5\%.

Table 4. Interaction effects of time of fertilizer application time and types of fertilizers of parameters studied of mung bean

\begin{tabular}{|c|c|c|c|c|c|c|}
\hline Treatments & $\begin{array}{c}\text { Plant } \\
\text { height }(\mathrm{cm})\end{array}$ & $\begin{array}{c}\text { Stem } \\
\text { thickness }(\mathrm{cm})\end{array}$ & $\begin{array}{c}\text { Number of branches } \\
\text { per plant }\end{array}$ & $\begin{array}{c}\begin{array}{c}\text { Number of } \\
\text { leaves per plant }\end{array} \\
\end{array}$ & $\begin{array}{c}\text { Fresh weight } \\
\left(\mathrm{kg} \mathrm{ha}^{-1}\right)\end{array}$ & $\begin{array}{c}\text { Dry weight } \\
\left(\mathrm{kg} \mathrm{ha}^{-1}\right)\end{array}$ \\
\hline B.S $\times$ C & $23.08 \mathrm{D}$ & $6 \mathrm{BC}$ & $7.85 \mathrm{D}$ & $27.31 \mathrm{C}$ & $471.8 \mathrm{E}$ & $101.8 \mathrm{D}$ \\
\hline B.S $\times$ O.M & $15.41 \mathrm{I}$ & $4.8 \mathrm{~F}$ & $6.25 \mathrm{H}$ & $20.50 \mathrm{I}$ & $218 \mathrm{~J}$ & $51.50 \mathrm{H}$ \\
\hline B.S $\times$ D.P & $24.85 \mathrm{~B}$ & $6.18 \mathrm{AB}$ & $8.37 \mathrm{C}$ & $26.63 \mathrm{D}$ & $482 \mathrm{D}$ & $103.8 \mathrm{D}$ \\
\hline B.S $\times$ H.A & $17.92 \mathrm{G}$ & $5.25 \mathrm{DE}$ & $6.62 \mathrm{G}$ & $21.69 \mathrm{H}$ & $420.3 \mathrm{~F}$ & $84.25 \mathrm{E}$ \\
\hline W.S $\times$ C & $23.90 \mathrm{C}$ & $5.37 \mathrm{D}$ & $7.56 \mathrm{E}$ & $25 \mathrm{E}$ & $372.8 \mathrm{G}$ & $85.25 \mathrm{E}$ \\
\hline $\mathrm{W} . \mathrm{S} \times \mathrm{O} . \mathrm{M}$ & $24.95 \mathrm{~B}$ & $5.8 \mathrm{C}$ & $8.68 \mathrm{~B}$ & $29 \mathrm{~B}$ & $537.5 \mathrm{C}$ & $116.5 \mathrm{C}$ \\
\hline W.S $\times$ D.P & $17.17 \mathrm{H}$ & $4.18 \mathrm{G}$ & $5.12 \mathrm{I}$ & $17.88 \mathrm{~J}$ & $146 \mathrm{~K}$ & $40 \mathrm{I}$ \\
\hline W.S $\times$ H.A & $20.83 \mathrm{E}$ & $4.81 \mathrm{~F}$ & $6.68 \mathrm{G}$ & $23.69 \mathrm{~F}$ & $302.8 \mathrm{I}$ & $71.75 \mathrm{~F}$ \\
\hline A.S $\times$ C & $17.46 \mathrm{H}$ & $5 \mathrm{EF}$ & $6.62 \mathrm{G}$ & $22.50 \mathrm{G}$ & $322 \mathrm{H}$ & $66 \mathrm{G}$ \\
\hline A.S $\times$ O.M & $28.78 \mathrm{~A}$ & $6.43 \mathrm{~A}$ & $9.37 \mathrm{~A}$ & $31.69 \mathrm{~A}$ & $815.8 \mathrm{~A}$ & $161 \mathrm{~A}$ \\
\hline A.S $\times$ D.P & $25.04 \mathrm{~B}$ & $6.12 \mathrm{ABC}$ & $8.62 \mathrm{~B}$ & $27.56 \mathrm{C}$ & $621.3 \mathrm{~B}$ & $130.5 \mathrm{~B}$ \\
\hline A.S $\times$ H.A & $19.21 \mathrm{~F}$ & $4.93 \mathrm{EF}$ & $7.06 \mathrm{~F}$ & $23.06 \mathrm{G}$ & $326 \mathrm{H}$ & $67 \mathrm{G}$ \\
\hline
\end{tabular}




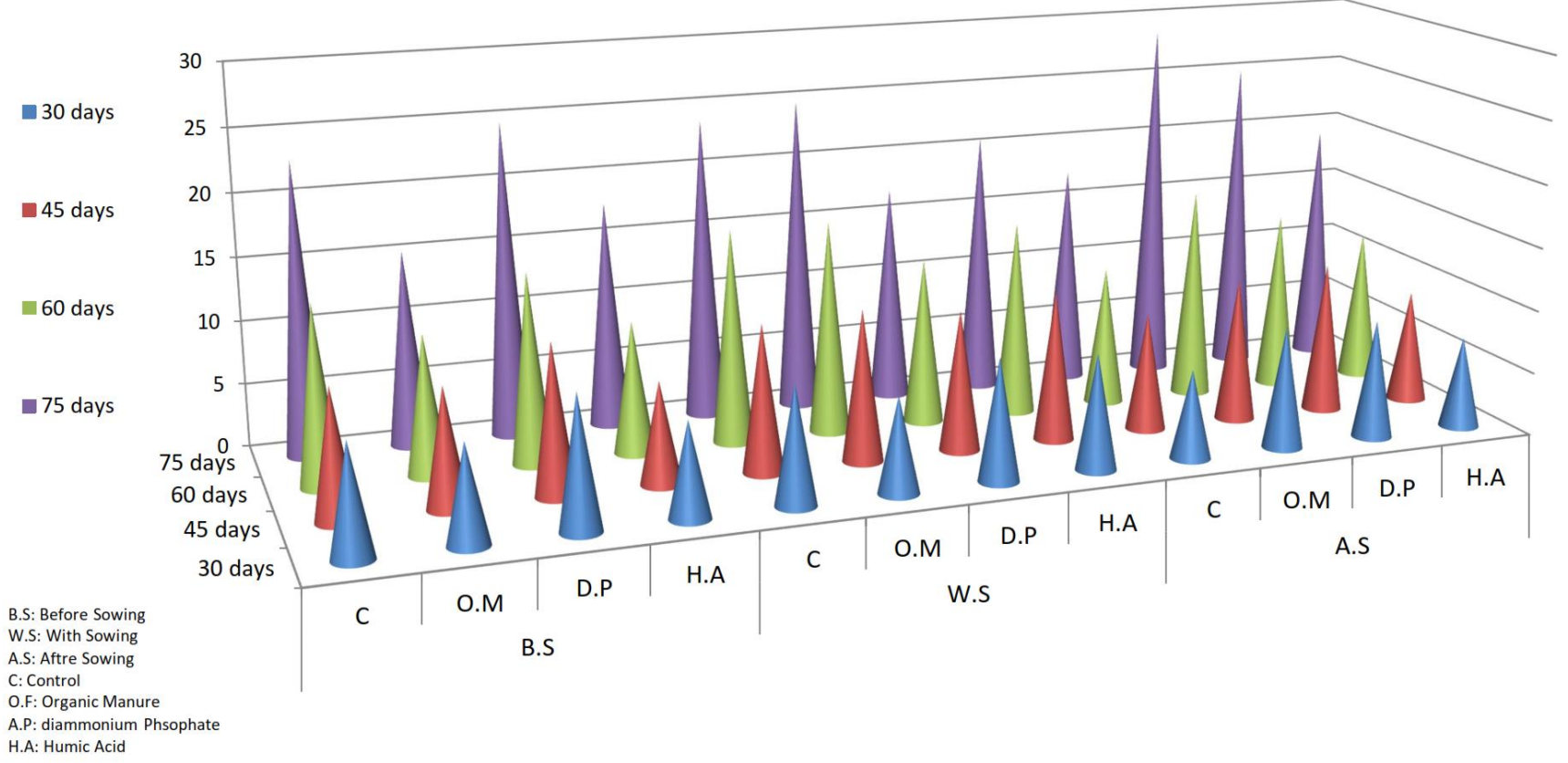

Figure 1. Mean values comparison of effect application time and fertilizers and their interaction of plant height growth on mung bean

The highest plant height was observed from the diammonium phosphate before sowing application $(10.3$ $\mathrm{cm})$ at 30 days, diammonium phosphate after sowing application, organic manure, and humic acid both application at sowing $(11.9 \mathrm{~cm})$ at 45 days, organic manure application at sowing $(16.8 \mathrm{~cm})$ at 60 days and organic manure application after sowing $(28.7 \mathrm{~cm})$ at 75 days. The lowest was observed after sowing control $(7 \mathrm{~cm})$ at 30 days, humic acid application before sowing $(8 \mathrm{~cm})$ at 45 days, humic acid application before sowing $(10.4 \mathrm{~cm})$ at 60 days and organic manure application before sowing (15.4 $\mathrm{cm}$ ) at 75days (Figure 1).

A similar trend was also found by Thakuni and Saharia (1990) and Salah et al. (2009) showed that in early growth stages such as up to 20 days after sowing (DAS) there was no significant difference among the treatments (Nitrogen, Phosphorus, Potassium and organic fertilizer (Bio fertilizer) but at later stage the highest plant height was observed from the organic fertilizer ( Bio fertilizer ) plots $(45.93 \mathrm{~cm}, 60.63 \mathrm{~cm}$, and $69.73 \mathrm{~cm})$ at 35 DAS, 50 DAS and 65 DAS respectively (Table 1) while lowest $(52.27 \mathrm{~cm})$ was observed with control at 65 DAS.

To summarize, producing leguminous crops such as mung bean for forage is considered an alternative method to provide supplemental protein. The humic acid, organic manure and diammonium phosphate as fertilizers can increase the quality and improve the output paving the way for sustainable agriculture. The major targets of this study were to examine the impact of humic acid, organic manure and diammonium phosphate fertilizers on growth and stover productivity of mung bean and determine optimum application time for enhancing mung bean productivity. To accomplish these objectives, three different applications time and four types of fertilizers were studied using an experimental factorial split plot with random complete blocks design with four replications. The results obtained from the present research work indicated that highly significant difference of time of fertilizer application and types of fertilizers and their interaction for growth characters of mung bean on plant height, number of leaves per plant, and fresh forage yield and dry forage yield were significantly differenced at $(\mathrm{p} \leq 0.01)$. There were highly significant differences of types of fertilizers and interaction between time of fertilizer application and types of fertilizers at $(p \leq 0.01)$ for number of branch per plant, significant difference of time of fertilizer application for number of branch per plant and stem thickness at ( $\mathrm{p} \leq$ $0.05)$, significant difference of interaction between time of fertilizer application for stem thickness at $p \leq 0.05$ and no significant difference of types of fertilizers at $(p=0.05)$ for stem diameter. The treatment of $50 \mathrm{~kg} \mathrm{ha}^{-1}$ of organic manure after sowing applications, gave highest plant height $(28.78 \mathrm{~cm})$, thick stem thickness $(6.43 \mathrm{~cm})$, optimized number of branches per plant (9.37), large number of leaves per plant (31.69), best fresh forage yield $\left(815 \mathrm{~kg} \mathrm{ha}^{-}\right.$ $\left.{ }^{1}\right)$ and dry forage yield $\left(161 \mathrm{~kg} \mathrm{ha}^{-1}\right)$ were recorded.

Based on findings of this study the attributes of mung bean combined application of $50 \mathrm{~kg} \mathrm{ha}^{-1}$ organic manure with application after sowing was considered the most balanced and suitable combination of fertilizer nutrients for achieving the maximum output of mung bean.

\section{REFERENCES}

Ali A, Choudhry A, Tanveer A. 2000. Response of mung bean (Vigna radiata L.) genotypes to rhizobia culture. Pak J Agric Sci 37 (1-2): 80-82. 
Sudan Ministry of Agriculture. 2015. Annual Statistics of Ministry of Agriculture, Animal Wealth \& Irrigation. Khartoum State. Statistics, Sudan.

ICAR. 2008. Agricultural Research Databook-2007. Indian Agricultural Statistics Research Institute, New Delhi.

Apioibedo S. 2014. Analysis of the Green gram Value Chain in Uganda. [Thesis]. Makerere University, Uganda.

Ali A. 1993. Effect of different planting methods and phosphorus levels on the performance of Vigna radiata. Pakistan J Agric Res 14 (2\&3): $162-168$.

Ashour NI, El-Hefni MZ, Darwish GG, Sharan AN, Selim MM, AbdelLateef EM, Yakout GM, Abou-Khadrah SH, Moslem ME. 1994. Effect of variety and plant density on mung bean (Vigna radiata $\mathrm{L}$. Wilczek) yield at different locations in Egypt. Proc. 6th Conf. Agron, Al-Azhar Univ, Cairo, Egypt.

Bhuiyan MMH, Rahman MM, Afroze F, Sutradhar GNC, Bhuiyan MSI 2008. Effect of phosphorus, molybdenum and Rhizobium inoculation on growth and nodulation of mung bean. J Soil Nature 2 (2): 25-30.

Bogdan AV. 1977. Tropical Pastures and Fodder Plants (Grasses And Legumes). Longman. Inc, New York.

Duncan DB. 1995. Multiple ranges and multiple F. Test. Biometrics 11: $1-42$.

El DM. 2004. Response of onion plants to humic acid and mineral fertilizers application. Ann Agric Sci Moshtohor 42 (2): 1955-1964

El-Banna EN, Ashour SA, Abd El-Salam H.Z. 2006. Effect of folia application with organic compounds on growth, yield and tubers quality of potato (Solanum tuberosum L.). J AgricSci Mansoura Univ 31: $1165-1175$

Gomez KA, Gomez A. 1984. Statistical Procedures for Agriculture Research. John Wiley \& Sons, New York

Hamdon HAM. 2001. Effect of Nitrogen Fertilization on Growth and Yield of Sunflower Harvest. [Hon. Thesis]. College Of Agriculture Studies. Sudan University of Science and Technology, Shambat. [Arabic]

Idris AY, El Nadi AH, Dagash YMI, Ali SAM. 2013. Comparative study of lucerne (Medicago sativa L.) under drip and sprinkler irrigation. Universal J Agric Res 1 (2): 17-23.

Zaid IU, Khalil IH, Khan S. 2012. Genetic variability and correlation analysis for yield components in mung bean (Vigna radiata $\mathrm{L}$. Wilczek). ARPN J Agric Biol Sci 7 (11): 885-891.

Iqbal S, Khan HZ, Shaheen H. 2012. Growth and yield responses of mung bean (Vigna radiata L.) to different levels of phosphorus application under different tillage systems. Intl. J Agric Sci 4 (1): 22-27.

Khairy AIH. 2010. Evaluation of Intercropping of Rhodes Grass with Alfalfa under Irrigation at Shambat, Department Of Agronomy, College Of Agriculture Studies. Sudan University of Science and Technology, Shambat, Sudan.

Liu P. 2001. The research development of molybdenum and boron nutrition in soybean. China Agri Sci Bull 17: 41-44.

Maarouf IM, Zeinab AZ. 2013. Quality Attributes in Sudanese Sorghums Improved for Forage Yield. Sudan University of Science and Technology, Shambat, Sudan.

Malihe B, Hamid RM, Alireza S. 2014. Effect of organic fertilizer on quantitative yield of mung bean (Vigna radiata $\mathrm{L}$ ). JNAS Journal 3 (4): $367-370$

Manpreet S, Sekhon HS, Jagrup S. 2004. Response of summer mung bean (Vigna radiata $\mathrm{L}$. Wilczek) genotypes to different phosphorus levels. Environ Ecol 22 (1): 13-17.

Maskey S, Bhattarai S, Karki K. 2004. Long-term effect of different sources of organic manures on wheat soybean rotation. SARC J Agric 2: $243-256$.

Minfal. 2008-2009. Agric. Statistics of Pakistan. Ministry of Food, Agric. and Livestock, Economic Wing, Islamabad.

Muhammad AA, Amjed A, Muhammad IA, Syed WH, Shahid RK, Amanat AA. 2014. Phosphorus effects on growth and yield parameters of mung bean. Sci Intl (Lahore) 26 (4): 1821-1824.

NCS. 1999. National Comprehensive Straitening in Sudan. eu.europa.eu/development/center/repository/scanned/sd-csp-en.pdf.
Nassar RMA. 2013. Response of mung bean plant (Vigna radiata (L.) Wilczek) to foliar spray with ascorbic acid. J Appl Sci Res 9 (4): 2731-2742.

Nemat A, Noureldin A, El-Hayatemy YY, Hamed MF, Ibrahim AM. 2000. Studies on mung bean (Vigna radiata L. Wilczek) varieties grown under phosphorus fertilizer and Rhizobium inoculation. 1Growth and growth analysis. Proc. 8th Conf. Agric. Development Res. Ain Shams, Cairo, Egypt. Ann Agric. Sci Sp. 3: 997-1008.

Odeyinka S, Okunade G. 2005. Goat production in Oyo State: a case study of Ogbomosho town. Nigerian J Anim Prod 32: 108-115.

Oladotun O, Ama A, Oguntona E. 2003. Evaluation of formulated agro industrial wastes as dry season feed for sheep. Nigerian J Anim Prod 30: 7-80.

O'lsen SR, Cole CV. 1954. Evaluation of available phosphorus in soil by extraction with $\mathrm{NaHCO}_{3}$. U.S. Dept. Agric. Circular No. 393, USA

Paroda RS, Thomas TA. 1987. Genetic resources of mung bean (Vigna radiata (L.) Wilczek) In India. In: Mung Bean, Proceedings of Second International Symposium, Bangkok, Thailand.

Ritchard A. 1954. Diagnosis and Improvement of Saline and Alkali Soil. Handbook No. 60. USDA, Washington DC.

Ryan JS, Hannsen GK, Rashid A. 1966. A Soil and plant Analysis Laboratory Manual, 2nd ed, ICARDA, Aleppo, Syria.

Ryan J, Estefan G, Rashid A. 2001. Soil and plant Analysis Manual Adapted for the West Asia and North Africa Region. ICARDA, Aleppo, Syria.

Salah UM, Ruhul AAKM, Jafar UM, Asaduzzman M. 2009. Interaction effect of variety and different fertilizers on the growth and yield of summer mung bean. Amer-Eur J Agron 2 (3): 180-184.

Sarwar M, Hyder SI, Akhtar EM, Tauseef T, Shahid RM. 2014. Integrated effects of humic acid and biofertilizer on yield and phosphorus use efficiency in mung bean under rainfed condition. World J Agric Sci 2 (3): 40-46.

Shanmugasundaram S, Keatinge JDH, Hughes J. 2009. Counting On Beans: Mung bean Improvement in Asia. In: Spielman D.J, PandyaLorch R Eds Millions Fed: Proven Successes in Agricultural Development, IFPRI, Washington DC.

Sharma AP, Singh R. 1997. Effect of phosphorus and sulphur on green gram (Vigna radiata L.). Indian J Agron 42 (3-4): 650-652.

Shukla SK, Dixit RS. 1996. Effect of Rhizobium inoculation, plant population and phosphorus on growth and yield of summer Mung bean (Vigna radiata). Indian J Agron 41 (4): 611-615.

Singh R, Agrawal M. 2007. Effects of sewage sludge amendment on heavy metal accumulation and consequent responses of Beta vulgaris plants. Chemosphere 67: 2229-2240.

Somashekaraiah B, Padmaja K, Prasad A. 1992. Phytotoxicity of cadmium ions on germinating seedlings of mung bean (Phaseolus vulgaris) involvement of lipid peroxides in chlorophyll degradation. Physiologia Plantarum 85 (1): 85-89.

Thakuria A, Saharia P. 1990. Response of mung bean genotypes to plant density and phosphorous levels in summer. Indian J Agron 35 (4): 431-432.

Twidwell EK, Boe A, Kephart KD. 1992. Planting date effects on yield and quality of foxtail millet and three annual legumes. Can J Plant Sci 72: 819-823.

Unkovich MJ, Pate JS, Sanford P. 1997. Nitrogen fixation in Australian Mediterranean agriculture. Aust J Agric Res 48: 267-293.

Walkley A, Black IA. 1934. An examination of the Degtjareff method for determining organic carbon in soil: Effect of variations in digestion conditions and of inorganic soil constituents. Soil Sci 63: 251-263.

Wanas SA, Shaaban SM, Abd El-Moez MR. 2007. Soil resistance and productivity of fodder beet grown in a clayey soil treated with compost. J Appl Sci Res 3 (4): 594-600.

Zaroug M G, Abul Aziz A M, Mahmoud H A. 1997. Forage and Pasture Seed Production in Sudan: An Overview. Forage and Pasture Seed Seminar, ICARDA/ILRI, Aleppo, Syria

Zahid M, Waqas A, Jamil S, Muhammad S, Muhammad AS, Muhammad AS. 2013. Effect of prolonged irrigated fodders on soil physical properties and agronomic water use efficiency. Nat Resour Conserv 1 (3): 77-93. 